\title{
PET/CT imaging for tumour response assessment to immunotherapy: current status and future directions
}

\author{
Marcus Unterrainer ${ }^{1 *}$, Michael Ruzicka ${ }^{2}$, Matthias P. Fabritius ${ }^{1}$, Lena M. Mittlmeier ${ }^{3}$, Michael Winkelmann', \\ Johannes Rübenthaler ${ }^{1}$, Matthias Brendel ${ }^{3}$, Marion Subklewe², Michael von Bergwelt-Baildon², Jens Ricke ${ }^{1}$, \\ Wolfgang G. Kunz ${ }^{1+}$ and Clemens C. Cyran ${ }^{1,4+}$
}

\begin{abstract}
Recent immunotherapeutic approaches have evolved as powerful treatment options with high anti-tumour responses involving the patient's own immune system. Passive immunotherapy applies agents that enhance existing anti-tumour responses, such as antibodies against immune checkpoints. Active immunotherapy uses agents that direct the immune system to attack tumour cells by targeting tumour antigens. Active cellular-based therapies are on the rise, most notably chimeric antigen receptor $T$ cell therapy, which redirects patient-derived $T$ cells against tumour antigens. Approved treatments are available for a variety of solid malignancies including melanoma, lung cancer and haematologic diseases. These novel immune-related therapeutic approaches can be accompanied by new patterns of response and progression and immune-related side-effects that challenge established imagingbased response assessment criteria, such as Response Evaluation Criteria in Solid tumours (RECIST) 1.1. Hence, new criteria have been developed. Beyond morphological information of computed tomography (CT) and magnetic resonance imaging, positron emission tomography (PET) emerges as a comprehensive imaging modality by assessing (patho-)physiological processes such as glucose metabolism, which enables more comprehensive response assessment in oncological patients. We review the current concepts of response assessment to immunotherapy with particular emphasis on hybrid imaging with ${ }^{18} \mathrm{~F}-\mathrm{FDG}-\mathrm{PET} / \mathrm{CT}$ and aims at describing future trends of immunotherapy and additional aspects of molecular imaging within the field of immunotherapy.
\end{abstract}

Keywords: Antigens (neoplasm), Fluorodeoxyglucose F18, Immunotherapy, Positron emission tomography computed tomography, Receptors (chimeric antigen)

\section{Key points}

- Novel response criteria are incorporating positron emission tomography (PET) imaging to assess immunotherapy efficacy.

- PET-based response criteria refine the assessment of response to immunotherapy.

\footnotetext{
* Correspondence: marcus.unterrainer@med.uni-muenchen.de

†Wolfgang G. Kunz and Clemens C. Cyran contributed equally to this work. 'Department of Radiology, University Hospital, LMU Munich, Marchioninistr. 15, 81377 Munich, Germany

Full list of author information is available at the end of the article
}

- PET can assist in detecting immune-related side effects.

- Novel PET-ligands targeting molecules in immunerelated pathways are under development.

\section{Background \\ Recent immunotherapeutic approaches have emerged as powerful treatment options with high anti-tumour re- sponses. These effects can be achieved by redirecting, stimulating, or genetically reprogramming the patient's own immune system to target cancer cells. Passive immunotherapy is the most frequent form of}

\section{Springer Open}

(c) The Author(s). 2020 Open Access This article is licensed under a Creative Commons Attribution 4.0 International License, which permits use, sharing, adaptation, distribution and reproduction in any medium or format, as long as you give appropriate credit to the original author(s) and the source, provide a link to the Creative Commons licence, and indicate if changes were made. The images or other third party material in this article are included in the article's Creative Commons licence, unless indicated otherwise in a credit line to the material. If material is not included in the article's Creative Commons licence and your intended use is not permitted by statutory regulation or exceeds the permitted use, you will need to obtain permission directly from the copyright holder. To view a copy of this licence, visit http://creativecommons.org/licenses/by/4.0/. 
immunotherapy, involving agents that enhance existing anti-tumour responses, such as antibodies against immune checkpoints such as cytotoxic T-lymphocyteassociated protein 4 (CTLA-4), programmed cell death protein (1 PD-1), and programmed death-ligand 1 (PDL1). Active immunotherapy uses agents that direct the immune system to attack tumour cells by targeting tumour antigens (e.g., vaccines such as Bacillus Calmette-Guérin in bladder cancer). Active cellular-based therapies are on the rise, most notably chimeric antigen receptor (CAR) $\mathrm{T}$ cell therapy, which redirects patientderived $T$ cells against tumour antigens [1-3].

These approaches are accompanied by novel patterns of response and progression, as clinical phenomena such as pseudoprogression or hyperprogression occur [4]; moreover, new aspects and manifestations of (immunerelated) side-effects to systemic treatments can be observed [5]. Beyond these clinical features, current immunotherapeutic approaches do also challenge previously established imaging approaches based on computed tomography $(\mathrm{CT})$ and magnetic resonance imaging. Beyond the assessment of the mere morphological extent, positron emission tomography (PET) imaging has emerged as comprehensive imaging modality by assessing (patho-)physiological processes and their changes to particular systemic treatments. Hence, combined hybrid imaging can highly influence the initial staging and the further clinical patient management in a high proportion of patients compared to morphological imaging only [6], as is currently for the clinical management of Hodgkin lymphoma [7].

This narrative work reviews the current concepts of response assessment to immunotherapy with a particular emphasis on combined hybrid imaging using ${ }^{18}$ F-FDG $\mathrm{PET} / \mathrm{CT}$ and aims at describing future trends of immunotherapy and additional aspects of molecular imaging within the field of immunotherapy.

\section{Immunotherapy: the state of the art}

The idea of utilising immune cells to eradicate malignant disease dates back to 1970, when Buckner et al. [8] reported the first successful allogeneic bone marrow transplantation in a patient suffering from leukaemia. This technique grew to become an indispensable means of treatment for many forms of haematologic malignancies. In contrast, recent immunotherapeutic approaches aim to achieve anti-tumour responses by redirecting, stimulating, or genetically reprogramming the patient's own immune system to target cancer cells. These strategies include antibody-based treatments, immune checkpoint inhibitors, and chimeric antigen receptor (CAR)- $\mathrm{T}$ cells as most prominent examples.

Monoclonal antibodies offer the opportunity to therapeutically target specific tumour-associated antigens. By opsonisation, they enable effector cells such as natural killer cells [9], phagocytes [10, 11], and the complement system [12] to kill the respective target cells. Rituximab, targeting the cluster of differentiation (CD) 20 protein, is the most common agent and became essential for clinical routine since its approval in 1998 by the European Medicines Agency (EMA) for the treatment of haematologic $B$ cell malignancies.

\section{Checkpoint inhibitors}

Checkpoint inhibitors count among the most groundbreaking therapeutic approaches to have been translated into clinical use. The discovery of their underlying mode of action has been awarded with the Nobel Prize in Physiology or Medicine in 2018. The programmed cell death 1 (PD-1) protein, its corresponding programmed death-ligand 1 (PD-L1) and cytotoxic $\mathrm{T}$ lymphocyteassociated protein 4 (CTLA-4) represent immune checkpoints that are targeted in clinical practice. PD-L1 is often overexpressed in tumour cells and interacts with the membrane bound PD- 1 on $\mathrm{T}$ cells, thus inhibiting $\mathrm{T}$ cell responses [1]. CTLA-4 is located intracellularly in resting $\mathrm{T}$ cells and translocates to the cell surface upon engagement of the $\mathrm{T}$ cell receptor, inhibiting activation of the $\mathrm{T}$ cell by competing for essential costimulatory binding sites and via inhibitory signalling [13]. Several checkpoint inhibitors have been approved for clinical use by the EMA and the United Stated Food and Drug Administration, first being Ipilimumab (anti-CTLA-4) in 2011, followed by others such as Nivolumab and Pembrolizumab (anti-PD-1).

\section{Bispecific T cell engagers and CAR-T cell therapy}

Antibody therapies have advanced over time and recently the concept of bispecific antibodies or "bispecific $\mathrm{T}$ cell engagers" came into the spotlight, as the first bispecific $T$ cell engager, Blinatumomab, was approved by the EMA in 2015 for use in relapsed or refractory Bprecursor acute lymphoblastic leukaemia. This antibody is composed of two single-chain variable fragments targeting CD19 or CD3, respectively [14]. The bispecific nature of the antibody allows to bring tumour and immune effector cells into close proximity, facilitating the induction of immune cell mediated apoptosis [15].

CAR-T cells constitute the latest breakthrough in clinical immuno-oncology, with the two CAR-T cell products Yescarta (axicabtagene ciloleucel) and Kymriah (tisagenlecleucel) receiving approval by the EMA in August 2018, shortly after approval in the USA. The treatment is based on genetic modification of patient-derived $\mathrm{T}$ cells, obtained by leukapheresis, followed by their reinfusion into the patient. The cells are equipped with artificial CARs, which are composed of an antibody-derived single-chain variable fragments, a transmembrane and a 
signalling domain [16]. The single-chain variable fragment allows recognition of surface bound tumourassociated antigens such as CD19, whereas physiological $\mathrm{T}$ cell receptors are restricted to recognition of antigen fragments presented via the major histocompatibility complex [2]. Upon antigen binding, the CAR induces activation, proliferation of and cytokine release by the $\mathrm{T}$ cells, followed by cytotoxic activity targeted against the respective cancer cells. So far, the EMA approval covers therapeutic use in relapsed or refractory diffuse large B cell lymphoma, primary mediastinal large B cell lymphoma (Yescarta) and B cell Acute lymphoblastic leukaemia (Kymriah).

The consequences of CAR-T cell approval for clinical reality are remarkable, as the overall response rates for Kymriah during pivotal studies in patients suffering from relapsed or refractory diffuse large B cell lymphoma reached $52 \%$, with $40 \%$ of the patients experiencing a complete response (CR), of whom $79 \%$ would remain relapse-free after 12 months of follow-up [17]. Yescarta demonstrated comparable efficacy with an objective response rate of $82 \%$ and a CR rate of $40 \%$ after a median follow-up time of 15.4 months $[18,19]$. The endpoint for both pivotal studies had been set at best overall response in more than $20 \%$ of patients, a value based on data of historical studies. The significance at which this endpoint was met implies the overwhelming impact the approval had on the perspective of lymphoma patients relapsing from initial treatment regimens.

\section{Conventional imaging: pseudoprogression and hyperprogression}

Standardised assessment of change in tumour burden is essential in the evaluation of therapies in cancer patients. Most clinical trials use tumour shrinkage (objective response) or development of progressive disease (PD) as endpoints and continuation or modification of therapy regimens depend on it. The Response Evaluation Criteria in Solid tumours (RECIST) guidelines were introduced by an international working group in 2000 [24] and revised in 2009 as RECIST 1.1 [20, 25]. RECIST is primarily based on the use of computed tomography (CT) and magnetic resonance imaging (Table 1). These criteria have been successfully validated in many studies, and today, most clinical trials on cancer therapies use them to evaluate objective tumour response even though, compared with chemotherapeutic drugs, tumours respond differently to newer drugs with other target mechanisms such as immunotherapeutics. Atypical response patterns such as pseudoprogression (where the tumour burden increases initially due to an increase in lesion size and/or occurrence of newly detectable tumour lesions with subsequent decrease in tumour burden) may lead to incorrect determination of the response status using RECIST [26].

Since tumour growth or newly detectable tumour lesions are generally classified as PD based on RECIST, pseudoprogression is not diagnosed correctly and may result in an erroneous discontinuation of treatment or

Table 1 Overview of criteria for anatomical response evaluation to immunotherapy

\begin{tabular}{|c|c|c|c|c|}
\hline \multirow{2}{*}{$\begin{array}{l}\text { Criteria (year) } \\
\text { [reference] }\end{array}$} & \multicolumn{4}{|l|}{ Categories } \\
\hline & Complete response & Partial response & Stable disease & Progressive disease \\
\hline $\begin{array}{l}\text { RECIST } 1.1 \\
(2009) \text { [20] }\end{array}$ & $\begin{array}{l}\text { - Disappearance of all TL/NTL } \\
\text { - Nodal } S A D<1.0 \mathrm{~cm} \\
\text { - No new lesions }\end{array}$ & $\begin{array}{l}\text { - } \geq 30 \% \text { decrease of tumour } \\
\text { burden relative to baseline } \\
\text { - No new lesions }\end{array}$ & $\begin{array}{l}\text { - Neither CR, PR, } \\
\text { nor PD }\end{array}$ & $\begin{array}{l}\text { - } \geq 20 \% \text { increase of tumour burden relative } \\
\text { to baseline } \\
\text { - Or progression of NTL } \\
\text { - Or new lesion(s) }\end{array}$ \\
\hline $\operatorname{irRC}(2009)$ [21] & $\begin{array}{l}\text { - Disappearance of all lesions } \\
\text { (measurable or not) } \\
\text { - No new lesions } \\
\text { - Confirmation by consecutive } \\
\text { CSI control in } \geq 4 \text { weeks }\end{array}$ & $\begin{array}{l}\text { - } \geq 50 \% \text { decrease of tumour } \\
\text { burden relative to baseline } \\
\text { - Confirmation by consecutive } \\
\text { CSI control in } \geq 4 \text { weeks }\end{array}$ & $\begin{array}{l}\text { - Neither CR, PR, } \\
\text { nor PD }\end{array}$ & $\begin{array}{l}\cdot \geq 25 \% \text { increase of tumour burden relative } \\
\text { to nadir } \\
\text { - New lesions added to tumour burden } \\
\text { - Confirmation by consecutive CSI control } \\
\text { in } \geq 4 \text { weeks }\end{array}$ \\
\hline irRECIST (2013) [22] & $\begin{array}{l}\text { - Disappearance of all TL/NTL } \\
\text { - Nodal SAD }<1.0 \mathrm{~cm} \\
\text { - No new lesions }\end{array}$ & $\begin{array}{l}\cdot \geq 30 \% \text { decrease of tumour } \\
\text { burden relative to baseline } \\
\text { - No new lesions }\end{array}$ & $\begin{array}{l}\text { - Neither CR, PR, } \\
\text { nor PD }\end{array}$ & $\begin{array}{l}\text { - } \geq 20 \% \text { increase of tumour burden } \\
\text { - And } \geq 5 \mathrm{~mm} \text { absolute increase in total } \\
\text { measured tumour burden relative to nadir } \\
\text { (i.e., minimum recorded tumour burden). } \\
\text { - Confirmation of progression in } \geq 4 \text { weeks } \\
\text { after suspected PD }\end{array}$ \\
\hline $\begin{array}{l}\text { iRECIST } \\
(2017) \text { [23] }\end{array}$ & $\begin{array}{l}\text { - Disappearance of all TL/NTL } \\
\text { - Nodal SAD }<1.0 \mathrm{~cm} \\
\text { - No new lesions }\end{array}$ & $\begin{array}{l}\text { - Decrease of tumour burden } \\
>30 \% \text { relative to baseline } \\
\text { - No new lesions }\end{array}$ & $\begin{array}{l}\text { - Neither CR, PR, } \\
\text { nor PD }\end{array}$ & $\begin{array}{l}\text { iUPD: PD RECIST } 1.1 \\
\text { iCPD: } \\
\text { - Confirmation } 4-8 \text { weeks later } \\
\text { - Any further size increase in TL sum }>5 \mathrm{~mm} \\
\text { - Any progression of NTL } \\
\text { - Any further size increase of the sum of new } \\
\mathrm{TL}>5 \mathrm{~mm} \\
\text { - Appearance of another new lesion }\end{array}$ \\
\hline
\end{tabular}


an unjustified exclusion of patients from clinical trials. To address this, the RECIST working group developed a modified guideline for response assessment to immunotherapy in 2017, called Immune RECIST (iRECIST) [23]. It is based on RECIST 1.1 guidelines and essentially has a new category of immune unconfirmed progression disease that requires to be confirmed by an additional, early follow-up scan within six to eight weeks. Immune unconfirmed progression disease should be considered carefully, as an increase in tumour size is still more likely to be true progression rather than pseudoprogression. The frequency of pseudoprogression varies between different tumour entities and is most frequently observed in melanoma patients (up to 13\%) [21, 27]. Notably, in iRECIST, the target response drives the timepoint response after patients had immune unconfirmed progressive disease. For example, new lesions develop on follow-up 1 and persist or have not fully disappeared in follow-up 2. Yet, the target lesion sum on follow-up 2 has then regressed to a partial response (PR) level compared to baseline (in the absence of any other manifestations of PD). This is considered overall immune partial response, not continued immune unconfirmed PD.

Another atypical response pattern related to immunotherapy is hyperprogression, a term with various definitions, meaning a pronounced acceleration of tumour growth [28-30]. If hyperprogression is suspected, treatment must be interrupted immediately, even though robust biomarkers are still pending. Beyond iRECIST, several other refined response criteria using morphological information were developed (see Table 1).

\section{PET/CT imaging of immunotherapy \\ ${ }^{18}$ F-FDG PET-based response assessment criteria}

In 1999, the European Organization for Research and Treatment of Cancer' (EORTC) first introduced PETbased, metabolic information in specified criteria for the response assessment of oncological diseases in general [31]. Of note, those were also the first PET-based criteria to be applied for monitoring of immunotherapy [32]. These EORTC criteria were then superseded by the PET Response Criteria in Solid tumours (PERCIST) published by Wahl et al. in 2009 [33]. Despite rather comparable classifications, PERCIST introduced the SUL-which is the standardised uptake value (SUV) corrected for the lean body mass-as an imaging parameter and made a tumour SUL 1.5-fold higher than the SUL of the nonaffected liver a prerequisite for an evaluable lesion. Moreover, the SUL $\mathrm{Seak}_{\text {is }}$ assessed within a spherical volume of interest in the site of the most metabolically active tumour manifestation.

In 2017, Cho et al. [34] prospectively compared different response criteria in a small set of patients undergoing immunotherapy in order to evaluate an optimised complementary fit between morphological and metabolic response parameters. The best combination of the assessed parameters were then transformed in new criteria and named PET/CT Criteria for Early Prediction of Response to Immune Checkpoint Inhibitor Therapy (PECRIT) [34]. Additional response criteria were suggested by the Heidelberg group by introducing PET Response Evaluation Criteria for Immunotherapy (PERC IMT), which moreover take into account the clinical relevance of the absolute amount of new lesions during immunotherapy $[35,36]$. For an overview, please see Table 2.

When dealing with lymphomas, specific criteria for response assessment were established. In 1999, the first standardised response criteria for lymphoma were introduced [37]. However, the issue of residual morphological masses remained unsolved. Hence, in 2007, Cheson criteria incorporated PET imaging for ${ }^{18} \mathrm{~F}$-FDG-avid lymphomas [38]. Based on the First International Workshop on PET in Lymphoma in Deauville, France, a newly established 5-point scale (i.e., the Deauville score) relative to blood-pool and liver activity (see Table 3 ) was introduced [39] and, as a consequence, was incorporated in the subsequent Lugano criteria in 2014 [40], which succeeded the Cheson criteria. In general, a Deauville score 1-3 during therapy is considered as $\mathrm{CR}$, whereas a score $4-5$ at the termination of treatment is considered a non-response.

In the light of immunotherapy, modified Lugano criteria (lymphoma response to immunomodulatory therapy criteria (LYRIC)) were proposed in 2016 to account for features specific for immunotherapy [41]. Here, the category indeterminate response (IR) was introduced when an increase of tumour burden, new lesions, or an increase of ${ }^{18} \mathrm{~F}$-FDG-avidity is observed, leading to a consequent follow-up imaging study within twelve weeks in order to rule out or confirm PD or pseudoprogression [41].

Most recently, in 2017, Response Evaluation Criteria in Lymphoma (RECIL) were established by an international working group [42]. RECIL aimed at homogenising response assessing in trials by modifying response criteria. Within this process, the role of ${ }^{18}$ F-FDG PET was reduced in favour of a more pronounced impact of CT-based changes, considering the potential alteration of glucose metabolism by immunomodulatory drugs that may obscure the tumour ${ }^{18}$ F-FDG-avidity [42]. In Table 4 , an overview of response criteria for lymphoma is provided.

\section{Response assessment to immunotherapy with ${ }^{18}$ F-FDG PET}

PET imaging was initially used for immunotherapy monitoring in patients with solid tumours. Given the early 
Table 2 Overview metabolic and combined response evaluation to immunotherapy

\begin{tabular}{|c|c|c|c|c|c|}
\hline \multirow{2}{*}{$\begin{array}{l}\text { Criteria (year) } \\
\text { [reference] }\end{array}$} & \multirow[t]{2}{*}{ Modality } & \multicolumn{4}{|l|}{ Categories } \\
\hline & & Complete response & Partial response & Stable disease & Progressive disease \\
\hline $\begin{array}{l}\text { EORTC } \\
(1999)[31]\end{array}$ & PET & $\begin{array}{l}\text { - Reduction of }{ }^{18} \mathrm{~F}-\mathrm{FDG} \text { uptake } \\
\text { to background levels }\end{array}$ & $\begin{array}{l}\cdot \geq 15 \% \text { reduction of } \\
{ }^{18} \text { F-FDG uptake }\end{array}$ & $\begin{array}{l}\text { - Neither CR, PR, } \\
\text { nor PD }\end{array}$ & $\begin{array}{l}\cdot \geq 25 \% \text { increase in }{ }^{18} \mathrm{~F}-\mathrm{FDG} \\
\text { uptake }\end{array}$ \\
\hline PERCIST (2009) [33] & PET & $\begin{array}{l}\text { - Reduction of }{ }^{18} \mathrm{~F}-\mathrm{FDG} \text { uptake } \\
\text { to the level of background } \\
\text { blood pool }\end{array}$ & $\begin{array}{l}\cdot \geq 30 \% \text { reduction in SUL } \\
\text { peak } \\
\cdot \text { Minimum of } 0.8 \text { SUL } \\
\text { units of measurable lesions }\end{array}$ & $\begin{array}{l}\text { - Neither CR, PR, } \\
\text { nor PD }\end{array}$ & $\begin{array}{l}\cdot>30 \% \text { increase in SUL peak } \\
\text { - Minimum of } 0.8 \text { SUL units of } \\
\text { measurable lesions }\end{array}$ \\
\hline PECRIT (2017) [34] & $\mathrm{PET} / \mathrm{CT}$ & $\begin{array}{l}\text { - Disappearance of all } \\
\text { metabolically active } \\
\text { tumours and TL } \\
\text { - SAD reduction target } \\
\text { lymph nodes }<10 \mathrm{~mm} \\
\text { - No new lesions }\end{array}$ & $\begin{array}{l}\cdot \geq 30 \% \text { reduction in SUL } \\
\text { peak } \\
\cdot \geq 30 \% \text { decrease in } \mathrm{TL} \\
\text { diameter sum }\end{array}$ & $\begin{array}{l}\text { - Neither CR, PR, } \\
\text { nor PD }\end{array}$ & $\begin{array}{l}\cdot>30 \% \text { increase in SUL peak } \\
\text { - Or new metabolically active lesion } \\
\cdot \text { - } 20 \% \text { increase in target lesion } \\
\text { diameter (minimum } 5 \mathrm{~mm} \text { ) } \\
\text { - Or new lesions }\end{array}$ \\
\hline PERCIMT (2018) [35] & $\mathrm{PET} / \mathrm{CT}$ & $\begin{array}{l}\text { - Complete resolution of } \\
\text { all }{ }^{18} \text { F-FDG-avid lesions } \\
\text { - No new FDG avid lesions }\end{array}$ & $\begin{array}{l}\text { - Complete resolution of } \\
\text { some }{ }^{18} \mathrm{~F}-\mathrm{FDG} \text {-avid lesions } \\
\text { - No new }{ }^{18} \mathrm{~F}-\mathrm{FDG} \text {-avid } \\
\text { lesions }\end{array}$ & $\begin{array}{l}\text { - Neither CR, PR, } \\
\text { nor PD }\end{array}$ & $\begin{array}{l}\cdot \geq 4 \text { new lesions with } \leq 10 \mathrm{~mm} \\
\text { functional diameter } \\
\text { - Or three or more new lesions } \\
\text { with }>10 \mathrm{~mm} \text { functional diameter } \\
\text { - Or two or more new lesions } \\
\text { with }>15 \text { mm functional diameter }\end{array}$ \\
\hline
\end{tabular}

CR Complete response, $C T$ Computed tomography, FDG Fluorodeoxyglucose, $P D$ Progressive disease, $P E T$ Positron emission tomography, $P R$ Partial response, SAD Short-axis diameter, SUL SUV corrected for lean body mass, TL Target lesions

and successful implementation of immunotherapy within the clinical workup of melanoma patients, the first PETbased response assessment using EORTC criteria was applied in melanoma patients [32]. Already at this early stage, the appearance of new lesions was not linked to progressive disease per se leading to potential misclassifications. Residual metabolic activity on ${ }^{18}$ F-FDG PET (similarly to the Deauville score assessment) in melanoma patients treated with anti-PD-1 agents was also associated with residual vital tumour masses. Vice versa, a loss of ${ }^{18} \mathrm{~F}$-FDG-avidity despite remaining morphological masses was associated with improved outcome; however, remaining residual ${ }^{18} \mathrm{~F}$-FDG-avidity despite clinical response was also observed, possibly due to immune infiltrates [43].

In a cohort of melanoma patients undergoing immunotherapy, several morphological and functional response assessment criteria were applied, but only a limited agreement among the applied criteria in terms of outcome prediction was observed. Hence, the

Table 3 Five-point Deauville score system

\begin{tabular}{ll}
\hline Score & Metabolic activity of lymphoma \\
\hline $\mathbf{1}$ & No ${ }^{18}$ F-FDG-uptake above background activity \\
$\mathbf{2}$ & ${ }^{18}$ F-FDG-uptake $\leq$ mediastinal blood pool activity \\
$\mathbf{3}$ & ${ }^{18}$ F-FDG-uptake between mediastinal blood pool and liver \\
$\mathbf{4}$ & activity \\
$\mathbf{5}$ & ${ }^{18}$ F-FDG-uptake moderately higher than liver activity \\
$\mathbf{X}$ & New areas of ${ }^{18}$ F-FDG-uptake unlikely related to lymphoma \\
\hline
\end{tabular}

FDG Fluorodeoxyglucose combination of parameters best suitable for prediction was established (PECRIT criteria) [34]. When dealing with immunotherapy using ipilimumab in melanoma, the Heidelberg group demonstrated that changes of SUV-based parameters in the disease course do not predict the individual outcome, whereas the number of new lesions and their extent during therapy was predictive for clinical outcome and allowed proper stratification [35] (see also Table 4).

As a consequence, PERCIMT criteria were also used for interim evaluation in melanoma patients undergoing immunotherapy and compared to EORTC criteria by stratifying patients with metabolic benefit (i.e., CR, PR, or SD) and those without (i.e., PD). Again, agreement of PERC IMT and EORTC was limited; although PERCIMT showed a significantly higher sensitivity for the prediction of clinical benefit than EORTC, both criteria were equally able to predict the absence of clinical benefit [36]. Hence, a recent position paper by the European Association of Nuclear Medicine critically discussed the added value of the PERCIMT criteria. Firstly, study conclusions were based on 41 patients only and secondly, EORTC criteria showed even slightly higher diagnostic performance for the detection of a missing clinical benefit compared to PERCIMT, without reaching the level of significance [35].

Beyond melanoma, a few studies have addressed the value of ${ }^{18}$ F-FDG PET imaging of non-small cell lung carcinoma (NSCLC) patients undergoing immunotherapy. Here, ${ }^{18} \mathrm{~F}$-FDG changes in terms of PERCIST criteria (compared to RECIST 1.1) were highly predictive for treatment efficacy in NSCLC patients undergoing nivolumab therapy even at an early stage of 1 month after 
Table 4 Overview of response criteria for lymphoma

\begin{tabular}{|c|c|c|c|c|}
\hline \multirow{2}{*}{$\begin{array}{l}\text { Criteria } \\
\text { (year) } \\
\text { [reference] }\end{array}$} & \multicolumn{4}{|l|}{ Categories } \\
\hline & Complete response & Partial response & Stable disease & Progressive disease \\
\hline $\begin{array}{l}\text { Lugano } \\
\text { (2014) [40] }\end{array}$ & $\begin{array}{l}\cdot \text { CT: reduction of lesions } \\
\text { to normal size } \\
\text { - PET: normalised }{ }^{18} \text { F-FDG- } \\
\text { uptake (DS 1-3) }\end{array}$ & $\begin{array}{l}\text { - } \mathrm{CT}: \geq 50 \% \text { reduction in SPD } \\
\text { of up to } 6 \text { lesions } \\
\text { - PET: reduced }{ }^{18} \mathrm{~F}-\mathrm{FDG}- \\
\text { uptake (DS } 4 \text { or } 5 \text { ) }\end{array}$ & $\begin{array}{l}\text { - CT: neither sufficient } \\
\text { change for PD nor PR } \\
\text { - PET: unchanged }{ }^{18} \mathrm{~F}-\mathrm{FDG}- \\
\text { uptake (DS } 4 \text { or } 5 \text { ) }\end{array}$ & $\begin{array}{l}\text { - CT: } \geq 50 \% \text { increase in SPD of lesions } \\
\text { - New lesion(s) } \\
\left.\text { - PET: increased }{ }^{18} \text { F-FDG-uptake (DS } 4 \text { or } 5\right) \\
\text { or new }{ }^{18} \text { F-FDG-avid lesions }\end{array}$ \\
\hline $\begin{array}{l}\text { LYRIC } \\
(2016) \text { [41] }\end{array}$ & - Same as Lugano & - Same as Lugano & - Same as Lugano & $\begin{array}{l}\text { Adapted from Lugano to indeterminate } \\
\text { response (IR) categories: } \\
\text { - IR }: \geq 50 \% \text { increase in SPD in } 12 \text { weeks } \\
\text { without clinical deterioration } \\
\text { - } \mathrm{I}_{2}:<50 \% \text { increase in SPD with new } \\
\text { lesion(s), or } \geq 50 \% \text { increase in SPD of a } \\
\text { lesion or set of lesions at any time } \\
\text { during treatment } \\
\text { - IR } \\
\text { increase in lesion size meeting criteria } \\
\text { for PD }\end{array}$ \\
\hline \multirow[t]{2}{*}{$\begin{array}{l}\text { RECIL } \\
(2017) \text { [42] }\end{array}$} & \multirow{2}{*}{$\begin{array}{l}\text { - } C T \text { : complete disappearance } \\
\text { of all TL and all nodes with } \\
\text { LD }<10 \mathrm{~mm} \\
\text { - PET: normalised }{ }^{18} \mathrm{~F} \text {-FDG- } \\
\text { uptake (DS 1-3) }\end{array}$} & $\begin{array}{l}\text { Partial response } \\
\text { - } C T: \geq 30 \% \text { decrease in SLD } \\
\text { of } T L, \text { but no } C R \\
\text { - PET: DS } 4 \text { or } 5\end{array}$ & \multirow[t]{2}{*}{$\begin{array}{l}\cdot \text { CT: }<10 \% \text { decrease or } \leq \\
20 \% \text { increase SLD of TL } \\
\cdot \text { PET: any DS }\end{array}$} & \multirow{2}{*}{$\begin{array}{l}\text { - } \mathrm{CT}:>20 \% \text { increase in SLD of TL } \\
\text { - For small lymph nodes }<15 \mathrm{~mm} \text { after } \\
\text { therapy, a minimum absolute increase } \\
\text { of } 5 \mathrm{~mm} \text { and the LD }>15 \mathrm{~mm} \\
\text { - New lesion(s) } \\
\text { - PET: any DS }\end{array}$} \\
\hline & & $\begin{array}{l}\text { Minor response } \\
\text { - Same as PR yet only } \geq 10 \% \\
\text { and }<30 \% \text { SLD decrease }\end{array}$ & & \\
\hline
\end{tabular}

CT Computed tomography, DS Deauville score, FDG Fluorodeoxyglucose, IR Indeterminate response, LD Long diameter, PD Progressive disease, $P E T$ Positron emission tomography, PR Partial response, SLD Sum of longest diameters, SPD Sum of perpendicular diameters, $T L$ Target lesions

treatment initiation and was shown to be an independent prognostic factor at multivariate analysis [44]. Also, response on ${ }^{18}$ F-FDG PET (using EORTC criteria) in NSCL $C$ patients undergoing atezolizumab therapy 6 weeks after initiation were predictive for the further morphological disease course on CT. Moreover, even patients with pseudoprogression could be identified by using ${ }^{18}$ F-FDG PET [45]. In addition, follow-up ${ }^{18}$ F-FDG PET imaging in patients classified as PD on PERCIST criteria was able to identify patients with pseudoprogression and immune dissociated-response in more than half of patients previously classified as PD. Importantly, improved clinical outcome was observed in these patients [46].

When dealing with haematologic malignancies, first reports of anti-PD1-therapy in Hodgkin lymphoma (HL) were published already in 2014 [47], where a combination of CT and PET/CT imaging was used in order to assess response to immunotherapy. The KEYNOTE-013 trial [48] applied the Cheson 2007 criteria [38]. These and their updated 2014 version, the Lugano criteria [40], were subsequently applied in several trials evaluating immunotherapy in HL [49-53], partly also in comparison to LYRIC criteria [54, 55].

Initially, the metabolic changes over time in patients with relapsed or refractory HL undergoing anti-PD-1treatment were described by Dercle et al. [56]. Subsequently, the same group demonstrated that a decrease of ${ }^{18}$ F-FDG-avidity in tumour and spleen as well as the general ${ }^{18}$ F-FDG-avid tumour burden 3 months after initiation of anti-PD-1-treatment were associated with improved clinical outcome [55]. Consequently, CTbased response evaluation had to be reclassified when additionally applying PET criteria in $44 \%$ of HL patients undergoing nivolumab. Among these, the majority showed complete metabolic response in contrast to CT (Fig. 1) with improved clinical outcome [57]. In the setting of early treatment response of HL and anti-PD-1treatment, both Lugano criteria and LYRIC performed equally with equivocal findings [58], a result that possibly relates to the rather rare occurrence of pseudoprogression in HL $[55,56,59]$.

With regard to $\mathrm{PET} / \mathrm{CT}$ imaging in CAR-T cell therapy, only limited data is available. Firstly, Shah et al. [60] demonstrated in a small set of diffuse large B cell lymphoma and follicular lymphoma that patients with complete remission of the metabolic tumour volume on ${ }^{18} \mathrm{~F}-\mathrm{FDG}$ PET 4 weeks after CAR-T cell therapy showed a longterm remission over 2 years and patients with remaining activity had an early relapse. Secondly, Wang et al. [61] showed that a higher ${ }^{18}$ F-FDG-avid tumour burden prior to therapy was associated with more severe CAR-T cell therapy-related side effects. Interestingly, this study also demonstrated that the phenomenon of pseudoprogression and local immune activation can also occur in patients undergoing CAR-T cell therapy (Fig. 2). Of note, several trials are underway evaluating the particular contribution of PET imaging in the course of CAR-T cell therapy (e.g., NCT03086954, NCT02476734). 


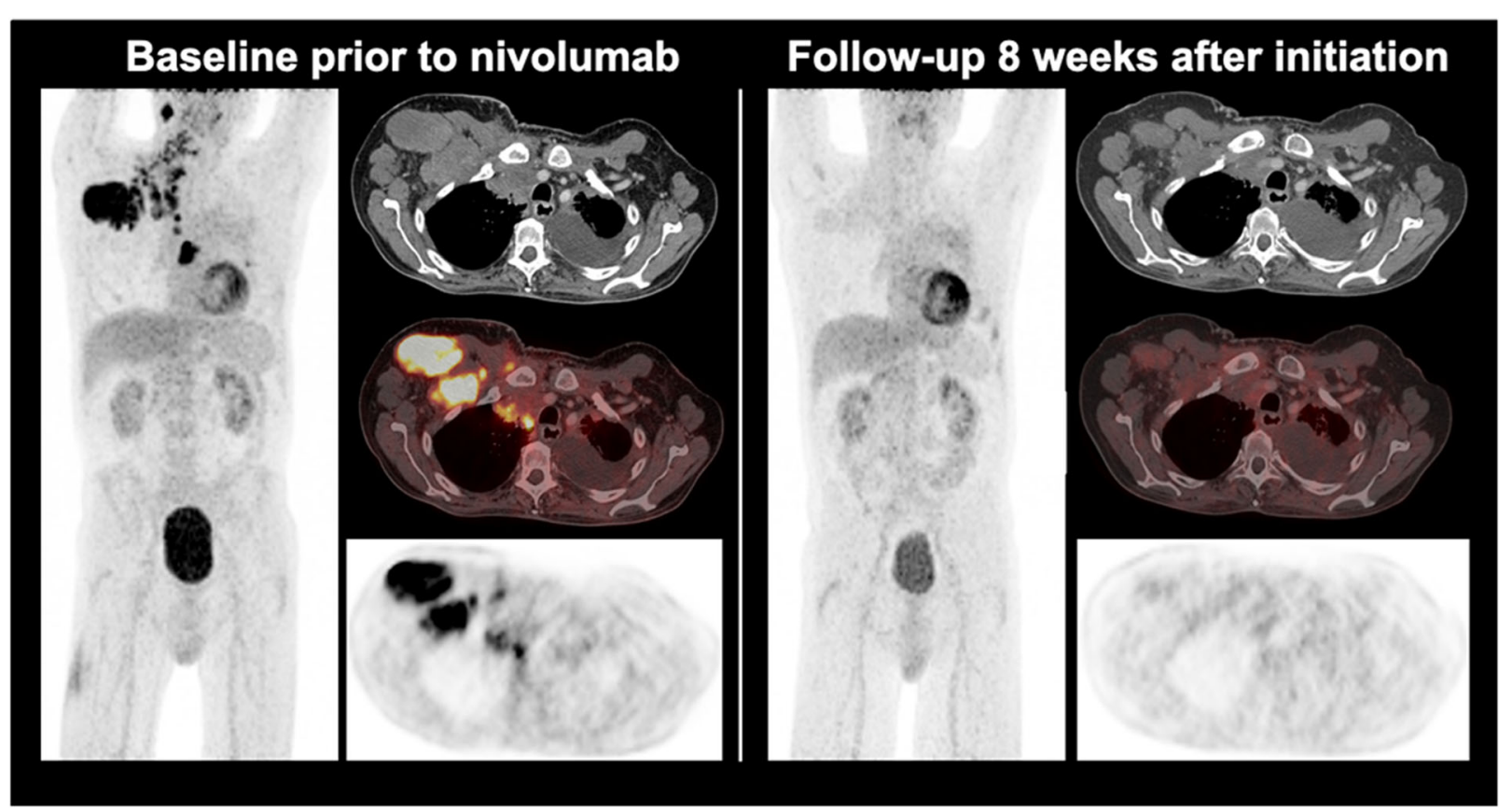

Fig. 1 A Hodgkin lymphoma patient with metabolically active tumour manifestations prior to the initiation of immunotherapy with nivolumab. A complete metabolic response already 8 weeks after immunotherapy initiation despite remaining morphological masses on CT was observed

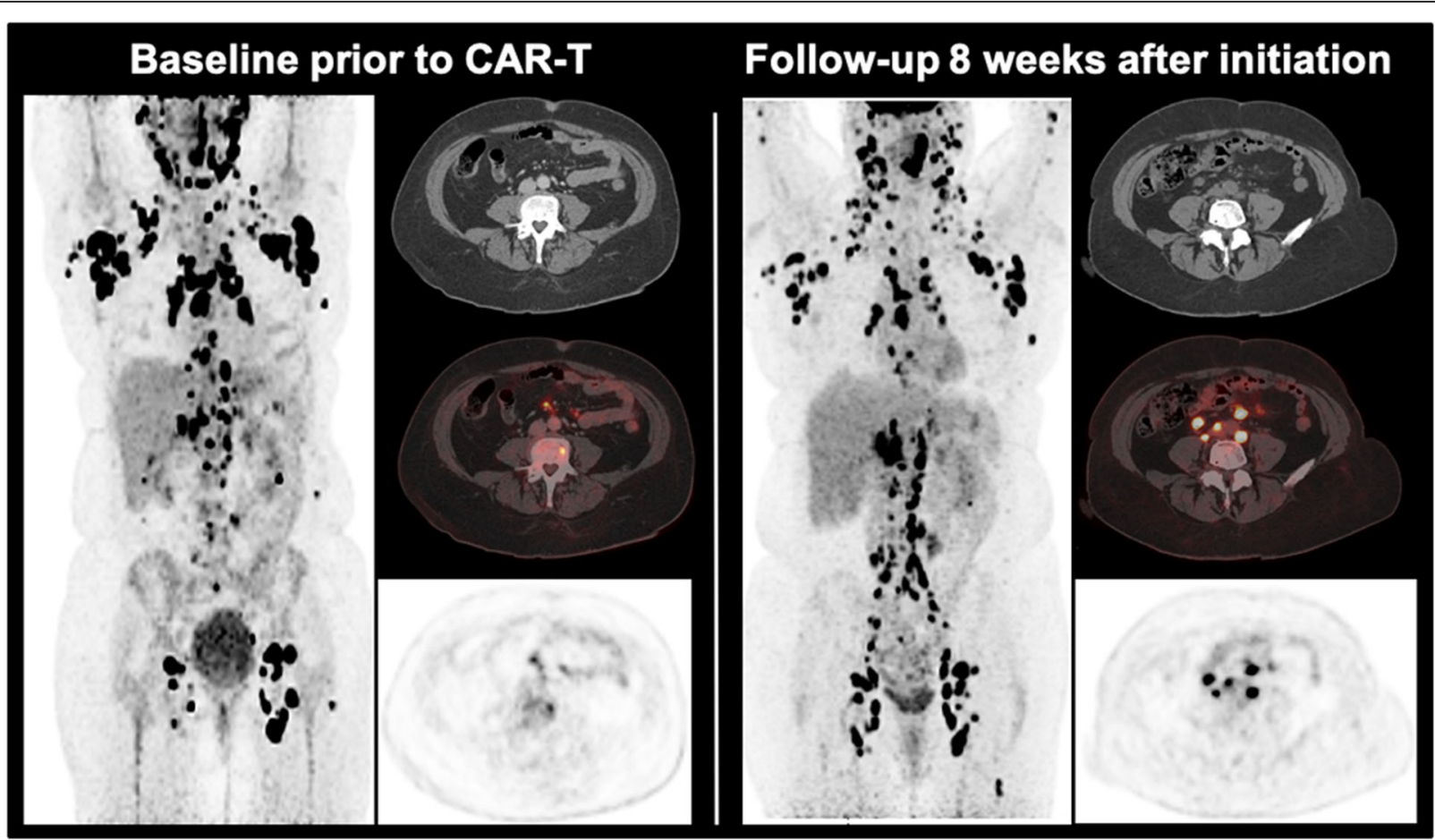

Fig. 2 A patient example with pseudoprogression of diffuse large B cell lymphoma undergoing chimeric antigen receptor $T$ (CAR-T) cell therapy. Eight weeks after reinfusion of CAR-T cells, numerous abdominal lymph nodes with highly increased metabolism occurred, but fully resolved in the further disease course without additional treatment 
So far, there is only limited literature dealing with the very exact clinical value of $\mathrm{PET} / \mathrm{CT}$ imaging for the identification of pseudo-progression in patients undergoing immunotherapy. One study in melanoma patients suggests that the new appearance of $\geq 4$ metabolically active lesions with a functional diameter $<1.0 \mathrm{~cm}$ or $\geq 3$ lesions $>1.0 \mathrm{~cm}$ is associated with real progression rather than the occurrence of pseudoprogression [35]. Another study identified that true progression was associated with a larger increase of metabolic tumour volume than pseudoprogression at the time of first follow-up [62]. More recent data indicated that metabolic changes of primary and secondary lymphoid organs during the course of immunotherapy in melanoma patients are associated with therapy response [63]; hence, these changes of lymphoid organs such as the spleen could potentially be useful for the differentiation of pseudo-progression and real progression. These interesting findings should be explored in further studies to assess their diagnostic value for early identification of patients with pseudoprogression.

\section{Imaging of immune-related adverse events}

During the application of immunotherapeutic agents, there is a reactivation of the immune system that not only has anti-tumour effects, but also might affect healthy tissue leading to new toxicity profiles that require a different management than the toxicity of chemotherapies $[64,65]$. These new immune-related adverse events (irAE) present with a broad variety of symptoms and might affect a multitude of organs. Most commonly, the cutaneous, gastrointestinal and endocrine systems are affected. However, some differences and diverging patterns of clinical manifestations can be observed depending on the checkpoint inhibitor and immunotherapy subgroups [66]. Nonetheless, a rapid identification of irAEs can improve the clinical outcome, as most of these irAEs are treated with subsequent systemic immunosuppression $[67,68]$.

The occurrence of irAEs can also affect response assessment with PET, as inflammatory reactions accompany these irAEs consequently leading to an elevated ${ }^{18}$ F-FDG-avidity [69], which might lead to a misinterpretation of the respective PET study. However, a

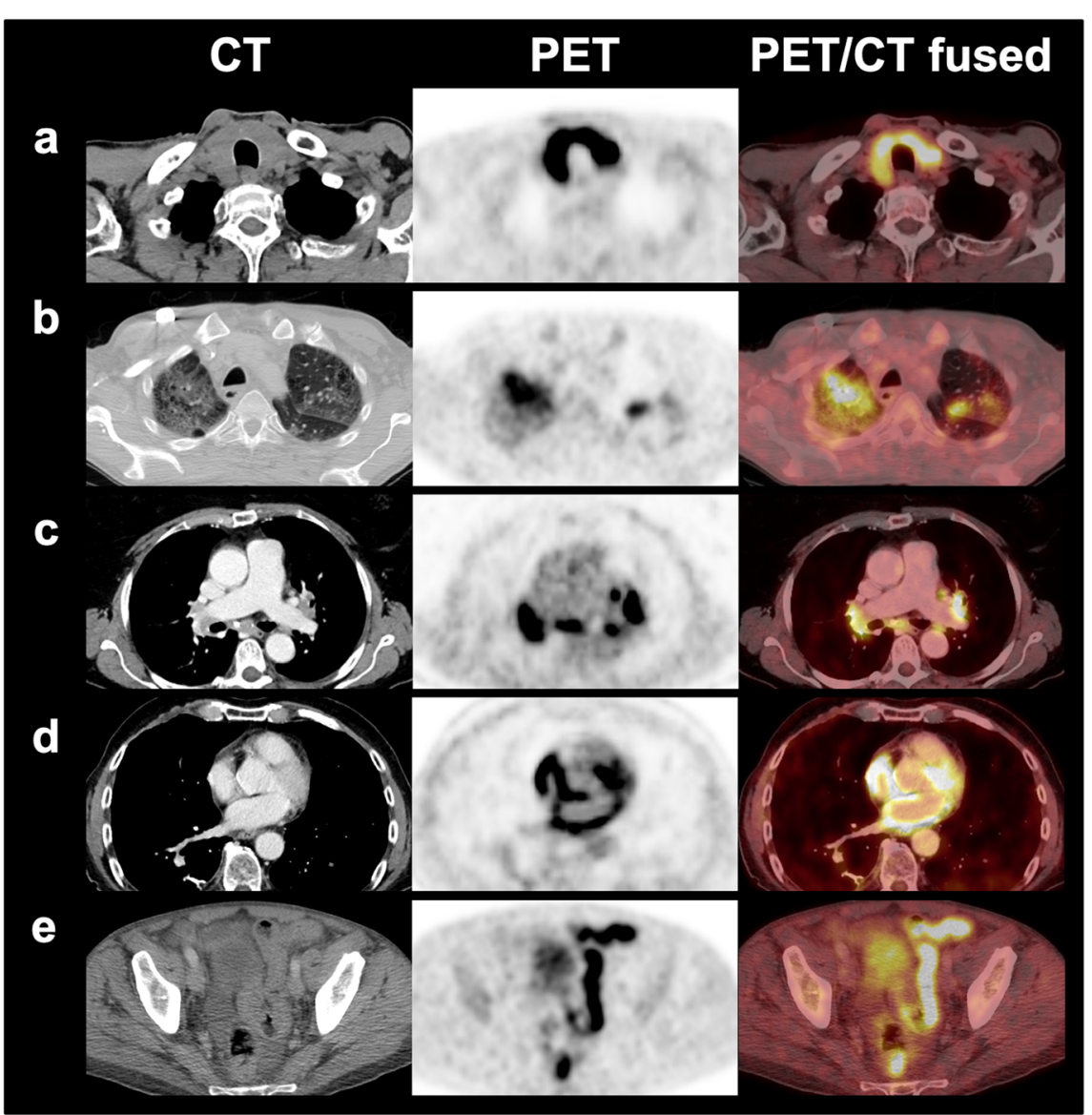

Fig. 3 Examples of immune-related adverse events on positron emission tomography/computed tomography with intensely increased ${ }^{18}$ F-FDG uptake. a Thyroiditis. b Pneumonitis. c Sarcoid-like reaction. d Pericarditis. e Colitis 
certain adaptation of ${ }^{18} \mathrm{~F}$-FDG-avidity can be observed over time [70, 71]. Vice versa, this ${ }^{18}$ F-FDG-avidity of irAEs also enables an exact localisation and identification [72], which gains further importance in the light of the association of occurrence of irAEs and the effectiveness of immunotherapy in melanoma and NSCLC patients $[5,73]$.

Recently, the report from the European Association of Nuclear Medicine symposium on immunotherapy stated that incidental findings related to irAEs should be reported. Although irAEs might not necessarily be associated with clinical symptoms, clinicians should be aware of their presence and ensure clinical monitoring, which, however, might lead to a clinical intervention. First signs of elevated immune activity can be seen as spleen enlargement and/or elevated uptake leading to an inversion of the liver-to-spleen uptake ratio. Also, reactive lymph nodes might be observed in the direct drainage of the tumour. However, these findings have to be compared to the respective baseline scan to assess their pathophysiological relevance, but also to safely relate these findings to the immunotherapy [74]. Moreover, the occurrence of immune-related sarcoid-like reactions consisting of lymphadenopathy and pulmonary granulomatosis with elevated glucose consumption have to be kept in mind [75]. This is also the most relevant irAE that may be misinterpreted as progression by mimicking newly developed mediastinal and hilar lymph node manifestations. The discordant course of other manifestations and the symmetry of these changes are helpful for the differentiation from malignant lesions (Fig. 3).

In CAR-T cell therapy, there is, however, another set of rather immediate adverse effects, such as cytokine release syndrome, CAR-T cell-related neurologic toxicities, and $B$ cell aplasia, which are not directly detectable using ${ }^{18}$ F-FDG-PET [61, 76, 77]. Moreover, CAR-T cell-related adverse events occur even earlier than irAEs, even hours and days after the first application. In sum, there is only a small amount of literature describing late toxicities different from irAEs so far [78, 79]. Hence, more clinical experience and, in particular, literature evaluating the use of PET imaging in CAR-T cell therapy are needed.

\section{Future directions}

\section{Novel treatments}

Despite growing success, immunotherapy, adoptive cell therapy in particular, still face many challenges. As the scientific community remains in search for answers as to why significant fractions of patients remain nonresponsive to immunotherapy, new targets for cellular treatments are validated in a fast-growing number of clinical trials.

In the context of haematologic malignancies, these new approaches include CAR-T cells targeted against B cell maturation antigen in relapsed or refractory multiple myeloma [80, 81] and CAR-T cells targeted against CD22 in acute lymphoblastic leukaemia, last of which managed to achieve stunning CR rates of over $80 \%$ in patients treated at the highest-dose level in a phase I trial $[3,82]$. Further, CAR-T cells are evaluated in multiple phase I and II trials for use in solid malignancies such as mesothelioma, metastatic pancreatic, gastric and prostate cancers, glioblastoma, sarcoma, and others [83].

Another emerging concept in cellular immunotherapy is universal or adapter CAR-T cells. The single-chain variable fragments of these CARs are designed to recognize antigens which are physiologically not present on the surface of tumour or healthy cells [84]. Application of tumour-specific ligands linked to such antigens allows them to serve as an adapter between the universal CAR and the respective tumour cell. This enables targeting of a broad variety of tumour antigens simultaneously or sequentially and without the need to engineer CAR-T cells for every single tumour under consideration, while at the same time providing better control of CAR-T cell activity $[85,86]$.

Taking the idea of universal immune cells further, recent reports demonstrate the potential of CARtransduced natural killer cells to combat lymphoma in a combined phase I and II trial [87]. Interestingly, natural killer cells do not mediate graft-versus-host-disease due to their lack of endogenous $\mathrm{T}$ cell receptors, allowing human leukocyte antigen mismatched transfusions [3]. These early data suggest that an off-the-shelf CAR product may be within reach, which eventually will be necessary to enable broad availability and affordability.

\section{Novel ligands for nuclear imaging}

Beyond morphological and glucose-based imaging, new molecular radiotracers arise that directly target the key molecules of immune checkpoint pathways and immune responses [88, 89]. Anti-PD-1 antibodies can be labeled with ${ }^{89} \mathrm{Zr}$ or ${ }^{64} \mathrm{Cu}$ and are suitable for in vivo imaging PD-1-expressing tumour-infiltrating lymphocytes [89], which might be an interesting approach for the noninvasive visualisation and quantification of PD-1expression, as immunohistochemical analyses are limited by the heterogeneous tissue expression on biopsies or single tissue specimen [90].

First studies were already performed in humans. Niemeijer et al. [91] published a study using radiolabeled anti-PD-1 monoclonal antibody ${ }^{89} \mathrm{Zr}$-nivolumab in patients with advanced NSCLC and showed a significant ${ }^{89} \mathrm{Zr}$-nivolumab tumour uptake, that was higher in patients with immunohistochemically proven PD-1 positive tumour-infiltrating immune cells as compared with PD-1 negative tumours. Interestingly, PD-(L)1 PET-CT demonstrated highly heterogeneous tumour uptake inter- 
individually, but also intra-individually with divergent uptake between different tumour lesions [90, 92]. Moreover, high uptake on pretreatment ${ }^{89} \mathrm{Zr}$-atezolizumab (an antibody to PD-L1) PET showed stronger correlation with the clinical outcome than immunohistochemistry- or ribonucleic acid-sequencing-based biomarkers in patients subsequently undergoing PD-L1-targeted therapies.

Several trials in humans aimed at establishing novel immuno-PET ligands in a broad range of cancer entities such as ${ }^{89} \mathrm{Zr}$-avelumab PET in NSCLC (NCT03514719, PINNACLE trial) or ${ }^{89} \mathrm{Zr}$-durvalumab in head-and-neck squamous cell cancer (NCT03829007, PINCH trial). Also, dual imaging approaches with ${ }^{18}$ F-FDG PET are on the way, for example combining ${ }^{18} \mathrm{~F}$-FDG PET and ${ }^{18}$ F-PD-L1 PET in oral cavity squamous cell cancer (NCT03843515, NeoNivo trial)

Beyond imaging PD-L1 using PET, several interesting biomarkers were introduced to molecular imaging in preclinical settings such as interferon- $\gamma$ immuno-PET $\left({ }^{89} \mathrm{Zr}-\right.$ anti-IFN- $\gamma$ ) that allows imaging of activated lymphocytes inside tumour lesions [93]. Another interesting target is represented by the protease granzyme B (GZP). It is secreted by cytotoxic CD8+ during immune-induced, caspase-dependent apoptosis. Targeting imaging with ${ }^{68}$ Ga-NOTA-GZP allowed prediction of response to immunotherapy with high accuracy in preclinical models [94]. Beyond the scope of PET imaging, also promising molecular structures can be targeted using single-photon emission tomography ligands. Among them, a very encouraging perspective is offered by ${ }^{99 \mathrm{~m}}$ Tc-labeled interleukin-2 ${ }^{99 \mathrm{~m}} \mathrm{Tc}$-HYNIC-IL2), which demonstrated feasibility for visualisation and quantification of tumour infiltrating lymphocytes in a small set of melanoma patients undergoing immunotherapy, so providing a potential non-invasive tool for the differentiation between progression and pseudoprogression [95].

These promising efforts in both preclinical and clinical setting underline the further investigation of immunoPET and the comprehensive translation into clinical imaging to further improve pretreatment patient selection, response assessment and clinical management. Moreover, artificial intelligence algorithms are increasingly used to evaluate treatment response by evaluating image-derived biomarkers [96, 97], which can also incorporate PET-derived information. Future trends also head towards integrated diagnostics', i.e., combining multiparametric diagnostic data from imaging, pathology, molecular genetics, and liquid biopsies, with final aim of therapy guidance.

\section{Abbreviations}

CAR: Chimeric antigen receptor; CD: Cluster of differentiation; CR: Complete response; CT: Computed tomography; CTLA-4: Cytotoxic T-lymphocyteassociated protein 4; EMA: European Medicines Agency; EORTC: European Organization for Research and Treatment of Cancer;
FDG: Fluorodeoxyglucose; GZP: Protease granzyme B; HL: Hodgkin Iymphoma; irAE: Immune-related adverse events; iRECIST: Immune Response Evaluation Criteria in Solid tumours; irRC: Immune-related response criteria; LYRIC: Lymphoma response to immunomodulatory therapy criteria; NSCL C: Non-small cell lung cancer; PD: Progressive disease; PD-1: Programmed cell death protein 1; PD-L1: Programmed death-ligand 1; PECRIT: PET/CT criteria for early prediction of response to immune checkpoint inhibitor therapy; PERCIMT: PET Response Evaluation Criteria for Immunotherapy; PERC IST: PET Response Criteria in Solid tumours; PET: Positron emission tomography; PR: Partial response; RECIL: Response evaluation criteria in lymphoma; RECIST: Response Evaluation Criteria in Solid tumours; SD: Stable disease; SUL: Standardised uptake value corrected for the lean body mass; SUV: Standardised uptake value

\section{Authors' contributions}

M.U.: conception, manuscript draft, literature review, increased intellectual content, revision. M.R.: manuscript draft, literature review, increased intellectual content, revision. M.P.F: manuscript draft, literature review, increased intellectual content, revision. L.M.M.: manuscript draft, literature review, increased intellectual content, revision. M.W.: literature review, increased intellectual content, revision. J.R.: literature review, increased intellectual content, revision. M.B.: literature review, increased intellectual content, revision. M.S.: literature review, increased intellectual content, revision. M.B.B.: literature review, increased intellectual content, revision. J.R. literature review, increased intellectual content, revision. W.G.K.: conception, literature review, increased intellectual content, revision. C. C. C.: conception, literature review, increased intellectual content, revision. All authors read and approved the final manuscript.

\section{Funding}

This study has not received any funding. Open Access funding enabled and organised by Projekt DEAL.

\section{Availability of data and materials}

Data sharing is not applicable to this article as no datasets were generated or analysed during the current study.

\section{Ethics approval and consent to participate}

No patient-related data was used; therefore, no additional statement from respective ethic committees was mandatory.

\section{Consent for publication}

Not mandatory as no datasets were generated or analysed during the current study.

\section{Competing interests}

All authors declare that they have no relationships or interests that could have direct or potential influence or impart bias on the work.

\section{Author details}

'Department of Radiology, University Hospital, LMU Munich, Marchioninistr. 15, 81377 Munich, Germany. ${ }^{2}$ Department of Medicine III, University Hospital, LMU Munich, Munich, Germany. ${ }^{3}$ Department of Nuclear Medicine, University Hospital, LMU Munich, Munich, Germany. ${ }^{4}$ DIE RADIOLOGIE, Munich, Germany.

Received: 3 July 2020 Accepted: 13 October 2020

Published online: 17 November 2020

\section{References}

1. Sharpe AH, Pauken KE (2018) The diverse functions of the PD1 inhibitory pathway. Nat Rev Immunol 18:153-167. https://doi.org/10.1038/nri.2017.108

2. Wang Z, Cao YJ (2020) Adoptive cell therapy targeting neoantigens: a frontier for cancer research. Front Immunol 11:176. https://dx.doi.org/10.33 89\%2Ffimmu.2020.00176

3. Weber EW, Maus MV, Mackall CL (2020) The emerging landscape of immune cell therapies. Cell 181:46-62. https://doi.org/10.1016/j.cell.2020.03. 001

4. Champiat S, Ferrara R, Massard C et al (2018) Hyperprogressive disease: recognizing a novel pattern to improve patient management. Nat Rev Clin Oncol 15:748-762. https://doi.org/10.1038/s41571-018-0111-2 
5. Friedman CF, Proverbs-Singh TA, Postow MA (2016) Treatment of the immune-related adverse effects of immune checkpoint inhibitors: a review. JAMA Oncol 2:1346-1353. https://doi.org/10.1001/jamaoncol.2016.1051

6. Delbeke D, Schöder H, Martin WH, Wahl RL (2009) Hybrid imaging (SPECT/ CT and PET/CT): improving therapeutic decisions. Semin Nucl Med 39:308340. https://doi.org/10.1053/j.semnuclmed.2009.03.002

7. Eichenauer DA, Aleman BMP, André M et al (2018) Hodgkin lymphoma: ESMO clinical practice guidelines for diagnosis, treatment and follow-up. Ann Oncol 29:iv19-iv29. https://doi.org/10.1093/annonc/mdy080

8. Buckner CD, Epstein RB, Rudolph RH, Clift RA, Storb R, Thomas ED (1970) Allogeneic marrow engraftment following whole body irradiation in a patient with leukemia. Blood 35:741-750

9. Wang W, Erbe AK, Hank JA, Morris ZS, Sondel PM (2015) NK cell-mediated antibody-dependent cellular cytotoxicity in cancer immunotherapy. Front Immunol 6:368. https://doi.org/10.3389/fimmu.2015.00368

10. Gul N, Babes L, Siegmund K et al (2014) Macrophages eliminate circulating tumour cells after monoclonal antibody therapy. J Clin Invest 124:812-823. https://doi.org/10.1172/jci66776

11. Montalvao F, Garcia Z, Celli S et al (2013) The mechanism of anti-CD20mediated B cell depletion revealed by intravital imaging. J Clin Invest 123: 5098-5103. https://doi.org/10.1172/jci70972

12. Rogers $L M$, Veeramani S, Weiner GJ (2014) Complement in monoclonal antibody therapy of cancer. Immunol Res 59:203-210. https://doi.org/10 1007/s12026-014-8542-z

13. Chambers CA, Kuhns MS, Egen JG, Allison JP (2001) CTLA-4-mediated inhibition in regulation of T cell responses: mechanisms and manipulation in tumour immunotherapy. Annu Rev Immunol 19:565-594. https://doi.org/ 10.1146/annurev.immunol.19.1.565

14. Franquiz MJ, Short NJ (2020) Blinatumomab for the treatment of adult B-cell acute lymphoblastic leukemia: toward a new era of targeted immunotherapy. Biologics 14:23-34. https://doi.org/10.2147/btt.s202746

15. Loffler A, Gruen M, Wuchter $C$ et al (2003) Efficient elimination of chronic lymphocytic leukaemia B cells by autologous T cells with a bispecific antiCD19/anti-CD3 single-chain antibody construct. Leukemia 17:900-909. https://doi.org/10.1038/sj.leu.2402890

16. Frigault MJ, Maus MV (2020) State of the art in CAR T cell therapy for CD19+ B cell malignancies. J Clin Invest 130:1586-1594. https://doi.org/10. 1172/jci129208

17. Schuster SJ, Bishop MR, Tam CS et al (2019) Tisagenlecleucel in adult relapsed or refractory diffuse large B-cell lymphoma. N Engl J Med 380:45-56. https://doi.org/10.1056/nejmoa1804980

18. Neelapu SS, Locke FL, Bartlett NL et al (2017) Axicabtagene ciloleucel CAR Tcell therapy in refractory large B-cell lymphoma. N Engl J Med 377:25312544. https://doi.org/10.1056/nejmoa1707447

19. Abbasi A, Peeke S, Shah N et al (2020) Axicabtagene ciloleucel CD19 CAR-T cell therapy results in high rates of systemic and neurologic remissions in ten patients with refractory large B cell lymphoma including two with HIV and viral hepatitis. J Hematol Oncol 13:1. https://doi.org/10.1186/s13045-019-0838-y

20. Eisenhauer EA, Therasse P, Bogaerts J et al (2009) New response evaluation criteria in solid tumours: revised RECIST guideline (version 1.1). Eur J Cancer 45:228-247. https://doi.org/10.1016/j.ejca.2008.10.026

21. Wolchok JD, Hoos A, O'Day S et al (2009) Guidelines for the evaluation of immune therapy activity in solid tumours: immune-related response criteria. Clin Cancer Res 15:7412-7420. https://doi.org/10.1158/1078-0432.ccr-09-1624

22. Bohnsack O, Hoos A, Ludajic K (2014) Adaptation of the immune related response criteria: irRECIST. Ann Oncol 25:iv369. https://doi.org/10.1093/ annonc/mdu342.23

23. Seymour L, Bogaerts J, Perrone A et al (2017) iRECIST: guidelines for response criteria for use in trials testing immunotherapeutics. Lancet Oncol 18:e143-e152. https://doi.org/10.1016/s1470-2045(17)30074-8

24. Therasse P, Arbuck SG, Eisenhauer EA et al (2000) New quidelines to evaluate the response to treatment in solid tumours. European Organization for Research and Treatment of cancer, National Cancer Institute of the United States, National Cancer Institute of Canada. J Natl Cancer Inst 92: 205-216. https://doi.org/10.1093/jnci/92.3.205

25. Schwartz LH, Litière S, de Vries E et al (2016) RECIST 1.1-update and clarification: from the RECIST committee. Eur J Cancer 62:132-137. https:// doi.org/10.1016/j.ejca.2016.03.081

26. Chiou VL, Burotto M (2015) Pseudoprogression and immune-related response in solid tumours. J Clin Oncol 33:3541-3543. https://doi.org/10. 1200/jco.2015.61.6870
27. Weber JS, D'Angelo SP, Minor D et al (2015) Nivolumab versus chemotherapy in patients with advanced melanoma who progressed after anti-CTLA-4 treatment (CheckMate 037): a randomised, controlled, openlabel, phase 3 trial. Lancet Oncol 16:375-384. https://doi.org/10.1016/s14702045(15)70076-8

28. Champiat S, Dercle L, Ammari S et al (2017) Hyperprogressive disease is a new pattern of progression in cancer patients treated by anti-PD-1/PD-L1. Clin Cancer Res 23:1920-1928. https:/doi.org/10.1158/1078-0432.ccr-16-1741

29. Saâda-Bouzid E, Defaucheux C, Karabajakian A et al (2017) Hyperprogression during anti-PD-1/PD-L1 therapy in patients with recurrent and/or metastatic head and neck squamous cell carcinoma. Ann Oncol 28:1605-1611. https:// doi.org/10.1093/annonc/mdx178v

30. Frelaut M, Le Tourneau C, Borcoman E (2019) Hyperprogression under immunotherapy. Int J Mol Sci 20:2674. https://doi.org/10.3390/ijms20112674

31. Young H, Baum R, Cremerius U et al (1999) Measurement of clinical and subclinical tumour response using [18F]-fluorodeoxyglucose and positron emission tomography: review and 1999 EORTC recommendations. Eur J Cancer 35:1773-1782. https://doi.org/10.1016/s0959-8049(99)00229-4

32. Sachpekidis C, Larribere L, Pan L, Haberkorn U, Dimitrakopoulou-Strauss A, Hassel JC (2015) Predictive value of early 18 F-FDG PET/CT studies for treatment response evaluation to ipilimumab in metastatic melanoma: preliminary results of an ongoing study. Eur J Nucl Med Mol Imaging 42: 386-396. https://doi.org/10.1007/s00259-014-2944-y

33. Wahl RL, Jacene H, Kasamon Y, Lodge MA (2009) From RECIST to PERCIST: evolving considerations for PET response criteria in solid tumours. J Nucl Med 50:122S-150S. https://doi.org/10.2967/jnumed.108.057307

34. Cho SY, Lipson EJ, Im H-J et al (2017) Prediction of response to immune checkpoint inhibitor therapy using early-time-point 18F-FDG PET/CT imaging in patients with advanced melanoma. J Nucl Med 58:1421-1428. https://doi.org/10.2967/jnumed.116.188839

35. Anwar H, Sachpekidis C, Winkler J et al (2018) Absolute number of new lesions on $18 \mathrm{~F}$-FDG PET/CT is more predictive of clinical response than SUV changes in metastatic melanoma patients receiving ipilimumab. Eur J Nucl Med Mol Imaging 45:376-383. https://doi.org/10.1007/s00259-017-3870-6

36. Sachpekidis C, Anwar H, Winkler J et al (2018) The role of interim 18 F-FDG $\mathrm{PET} / \mathrm{CT}$ in prediction of response to ipilimumab treatment in metastatic melanoma. Eur J Nucl Med Mol Imaging 45:1289-1296. https://doi.org/10. 1007/s00259-018-3972-9

37. Cheson BD, Horning SJ, Coiffier B et al (1999) Report of an international workshop to standardize response criteria for non-Hodgkin's lymphomas. J Clin Oncol 17:1244. https://doi.org/10.1200/jco.1999.17.4.1244

38. Cheson BD, Pfistner B, Juweid ME et al (2007) Revised response criteria for malignant lymphoma. J Clin Oncol 25:579-586. https://doi.org/10.1200/jco. 2006.09.2403

39. Meignan M, Gallamini A, Meignan M, Gallamini A, Haioun C (2009) Report on the first international workshop on interim-PET scan in lymphoma. Leuk Lymphoma 50:1257-1260. https://doi.org/10.1080/10428190903040048

40. Cheson BD, Fisher RI, Barrington SF et al (2014) Recommendations for initial evaluation, staging, and response assessment of Hodgkin and non-Hodgkin Iymphoma: the Lugano classification. J Clin Oncol 32:3059-3068. https://doi. org/10.1200/jco.2013.54.8800

41. Cheson BD, Ansell S, Schwartz L et al (2016) Refinement of the Lugano classification lymphoma response criteria in the era of immunomodulatory therapy. Blood 128:2489-2496. https://doi.org/10.1182/blood-2016-05-718528

42. Younes A, Hilden P, Coiffier B et al (2017) International working group consensus response evaluation criteria in lymphoma (RECIL 2017). Ann Oncol 28:1436-1447. https://doi.org/10.1093/annonc/mdx097

43. Kong BY, Menzies AM, Saunders CA et al (2016) Residual FDG-PET metabolic activity in metastatic melanoma patients with prolonged response to antiPD-1 therapy. Pigment Cell Melanoma Res 29:572-577. https://doi.org/10. $1111 /$ pcmr.12503

44. Kaira K, Higuchi T, Naruse I et al (2018) Metabolic activity by 18 F-FDG-PET/ $\mathrm{CT}$ is predictive of early response after nivolumab in previously treated NSCLC. Eur J Nucl Med Mol Imaging 45:56-66. https://doi.org/10.1007/ s00259-017-3806-1

45. Spigel DR, Chaft JE, Gettinger $S$ et al (2018) FIR: efficacy, safety, and biomarker analysis of a phase II open-label study of atezolizumab in PD-L1selected patients with NSCLC. J Thorac Oncol 13:1733-1742. https://doi.org/ 10.1016/j.jtho.2018.05.004

46. Humbert O, Cadour N, Paquet M et al (2020) 18FDG PET/CT in the early assessment of non-small cell lung cancer response to immunotherapy: 
frequency and clinical significance of atypical evolutive patterns. Eur J Nucl Med Mol Imaging 47:1158-1167. https://doi.org/10.1007/s00259-019-04573-4

47. Ansell SM, Lesokhin AM, Borrello I et al (2015) PD-1 blockade with nivolumab in relapsed or refractory Hodgkin's lymphoma. N Engl J Med 372:311-319. https://doi.org/10.1056/nejmoa1411087

48. Armand P, Shipp MA, Ribrag V et al (2016) Programmed death-1 blockade with pembrolizumab in patients with classical Hodgkin lymphoma after brentuximab vedotin failure. J Clin Oncol 34:3733-3739. https://doi.org/10. 1200/jco.2016.67.3467

49. Chen R, Zinzani PL, Fanale MA et al (2017) Phase II study of the efficacy and safety of pembrolizumab for relapsed/refractory classic Hodgkin lymphoma. J Clin Oncol 35:2125-2132. https://doi.org/10.1200/jco.2016.72.1316

50. Armand P, Engert A, Younes A et al (2018) Nivolumab for relapsed/ refractory classic Hodgkin lymphoma after failure of autologous hematopoietic cell transplantation: extended follow-up of the multicohort single-arm phase II CheckMate 205 trial. J Clin Oncol 36:1428-1439. https:// doi.org/10.1200/jco.2017.76.0793

51. Moskowitz CH, Zinzani PL, Fanale MA et al (2016) Pembrolizumab in relapsed/refractory classical Hodgkin lymphoma: primary end point analysis of the phase 2 Keynote-087 study. Blood 128:1107-1107

52. Maruyama D, Hatake K, Kinoshita T et al (2017) Multicenter phase II study of nivolumab in Japanese patients with relapsed or refractory classical Hodgkin lymphoma. Cancer Sci 108:1007-1012. https://doi.org/10.1111/cas. 13230

53. Chan TSY, Luk T-H, Lau JSM, Khong P-L, Kwong Y-L (2017) Low-dose pembrolizumab for relapsed/refractory Hodgkin lymphoma: high efficacy with minimal toxicity. Ann Hematol 96:647-651. https://doi.org/10.1007/ s00277-017-2931-z

54. Rossi C, Gilhodes J, Maerevoet M et al (2018) Efficacy of chemotherapy or chemoanti-PD-1 combination after failed anti-PD-1 therapy for relapsed and refractory hodgkin lymphoma: a series from lysa centers. Am J Hematol 93:1042-1049. https:// doi.org/10.1002/ajh.25154

55. Dercle L, Seban R-D, Lazarovici J et al (2018) 18F-FDG PET and CT scans detect new imaging patterns of response and progression in patients with Hodgkin lymphoma treated by anti-programmed death 1 immune checkpoint inhibitor. J Nucl Med 59:15-24. https://doi.org/10.2967/jnumed.117.193011

56. Dercle L, Ammari S, Seban R-D et al (2018) Kinetics and nadir of responses to immune checkpoint blockade by anti-PD1 in patients with classical Hodgkin lymphoma. Eur J Cancer 91:136-144. https://doi.org/10.1016/j.ejca. 2017.12.015

57. Mokrane F-Z, Chen A, Schwartz LH et al (2020) Performance of CT compared with 18F-FDG PET in predicting the efficacy of nivolumab in relapsed or refractory Hodgkin lymphoma. Radiology 295:651-661. https:// doi.org/10.1148/radiol.2020192056

58. Chen A, Mokrane F-Z, Schwartz LH et al (2020) Early 18F-FDG PET/CT response predicts survival in relapsed or refractory Hodgkin lymphoma treated with Nivolumab. J Nucl Med 61:649-654. https://doi.org/10.2967/ jnumed.119.232827

59. Castello A, Grizzi F, Qehajaj D, Rahal D, Lutman F, Lopci E (2019) 18F-FDG PET/CT for response assessment in Hodgkin lymphoma undergoing immunotherapy with checkpoint inhibitors. Leuk Lymphoma 60:367-375. https://doi.org/10.1080/10428194.2018.1488254

60. Shah NN, Nagle SJ, Torigian DA et al (2018) Early positron emission tomography/computed tomography as a predictor of response after CTL019 chimeric antigen receptor -T-cell therapy in B-cell non-Hodgkin lymphomas. Cytotherapy 20:1415-1418. https:/doi.org/10.1016/j.jcyt.2018.10.003

61. Wang J, Hu Y, Yang S et al (2019) Role of fluorodeoxyglucose positron emission tomography/computed tomography in predicting the adverse effects of chimeric antigen receptor $t$ cell therapy in patients with nonHodgkin lymphoma. Biol Blood Marrow Transplant 25:1092-1098. https:// doi.org/10.1016/j.bbmt.2019.02.008

62. Basler L, Gabryś HS, Hogan SA et al (2020) Radiomics, tumour volume and blood biomarkers for early prediction of pseudoprogression in metastatic melanoma patients treated with immune checkpoint inhibition. Clin Cancer Res. https://doi. org/10.1158/1078-0432.CCR-20-0020

63. Seith F, Forschner A, Weide B et al (2020) Is there a link between very early changes of primary and secondary lymphoid organs in (18)F-FDG-PET/MRI and treatment response to checkpoint inhibitor therapy? J Immunother Cancer 8: e000656. https://dx.doi.org/10.1136\%2Fjitc-2020-000656

64. Cousin S, Italiano A (2016) Molecular pathways: immune checkpoint antibodies and their toxicities. Clin Cancer Res 22:4550-4555
65. Nishijima TF, Shachar SS, Nyrop KA, Muss HB (2017) Safety and tolerability of PD-1/PD-L1 inhibitors compared with chemotherapy in patients with advanced cancer: a meta-analysis. Oncologist 22:470. https://doi.org/10. 1634/theoncologist.2016-0419

66. Khoja L, Day D, Wei-Wu Chen T, Siu L, Hansen A (2017) Tumour-and classspecific patterns of immune-related adverse events of immune checkpoint inhibitors: a systematic review. Ann Oncol 28:2377-2385. https://doi.org/10. 1093/annonc/mdx286

67. Foppen $M H G$, Rozeman EA, van Wilpe $S$ et al (2018) Immune checkpoint inhibition-related colitis: symptoms, endoscopic features, histology and response to management. ESMO open 3:e000278. https://doi.org/10.1136/ esmoopen-2017-000278

68. Fujii T, Colen RR, Bilen MA et al (2018) Incidence of immune-related adverse events and its association with treatment outcomes: the MD Anderson Cancer Center experience. Investig New Drugs 36:638-646. https://doi.org/ 10.1007/s10637-017-0534-0

69. Rossi S, Toschi L, Castello A, Grizzi F, Mansi L, Lopci E (2017) Clinical characteristics of patient selection and imaging predictors of outcome in solid tumours treated with checkpoint-inhibitors. Eur J Nucl Med Mol Imaging 44:2310-2325. https://doi.org/10.1007/s00259-017-3802-5

70. Tsai KK, Pampaloni MH, Hope C et al (2016) Increased FDG avidity in lymphoid tissue associated with response to combined immune checkpoint blockade. J Immunother Cancer 4:58. https://doi.org/10.1186/s40425-0160162-9

71. Wachsmann JW, Ganti R, Peng F (2017) Immune-mediated disease in ipilimumab immunotherapy of melanoma with FDG PET-CT. Acad Radiol 24:111-115. https:/ doi.org/10.1016/.acra.2016.08.005

72. Nobashi T, Baratto L, Reddy SA et al (2019) Predicting response to immunotherapy by evaluating tumours, lymphoid cell-rich organs, and immunerelated adverse events using FDG-PET/CT. Clin Nucl Med 44:e272-e279. https:/ doi.org/10.1097/rlu.0000000000002453

73. Haratani K, Hayashi H, Chiba Y et al (2018) Association of immune-related adverse events with nivolumab efficacy in non-small-cell lung cancer. JAMA Oncol 4:374-378. https://doi.org/10.1001/jamaoncol.2017.2925

74. Aide N, Hicks RJ, Le Tourneau C, Lheureux S, Fanti S, Lopci E (2019) FDG PET/CT for assessing tumour response to immunotherapy. Eur J Nucl Med Mol Imaging 46:238-250. https://doi.org/10.1007/s00259-018-4171-4

75. Nishino M, Hatabu H, Hodi FS (2019) Imaging of cancer immunotherapy: current approaches and future directions. Radiology 290:9-22. https://doi. org/10.1148/radiol.2018181349

76. Brudno JN, Kochenderfer JN (2016) Toxicities of chimeric antigen receptor T cells: recognition and management. Blood 127:3321-3330. https://doi.org/ 10.1182/blood-2016-04-703751

77. Neelapu SS, Tummala S, Kebriaei P et al (2018) Chimeric antigen receptor Tcell therapy — assessment and management of toxicities. Nat Rev Clin Oncol 15:47-62. https://doi.org/10.1038/nrclinonc.2017.148

78. Hu Y, Wang J, Pu C et al (2018) Delayed terminal ileal perforation in a relapsed/refractory B-cell lymphoma patient with rapid remission following chimeric antigen receptor T-cell therapy. Cancer Res Treat 50:1462-1466. https://doi.org/10.4143/crt.2017.473

79. Wang Y, Zhang W-y, Han Q-w et al (2014) Effective response and delayed toxicities of refractory advanced diffuse large B-cell lymphoma treated by CD20-directed chimeric antigen receptor-modified T cells. Clin Immunol 155:160-175. https://doi.org/10.1016/j.clim.2014.10.002

80. Cohen AD, Garfall AL, Stadtmauer EA et al (2019) B cell maturation antigenspecific CAR T cells are clinically active in multiple myeloma. J Clin Invest 129:2210-2221. https://doi.org/10.1172/jci126397

81. Raje N, Berdeja J, Lin Y et al (2019) Anti-BCMA CAR T-cell therapy bb2121 in relapsed or refractory multiple myeloma. N Engl J Med 380:1726-1737. https://doi.org/10.1056/nejmoa1817226

82. Fry TJ, Shah NN, Orentas RJ et al (2018) CD22-targeted CAR T cells induce remission in B-ALL that is naive or resistant to CD19-targeted CAR immunotherapy. Nat Med 24:20-28. https://doi.org/10.1038/nm.4441

83. Titov A, Valiullina A, Zmievskaya E et al (2020) Advancing CAR T-cell therapy for solid tumours: lessons learned from lymphoma treatment. Cancers (Basel) 12: 125. https://doi.org/10.3390/cancers12010125

84. Bachmann M (2019) The UniCAR system: a modular CAR T cell approach to improve the safety of CAR T cells. Immunol Lett 211:13-22. https://doi.org/ 10.1016/j.imlet.2019.05.003

85. Lee YG, Marks I, Srinivasarao M et al (2019) Use of a single CAR T cell and several bispecific adapters facilitates eradication of multiple antigenically 
different solid tumours. Cancer Res 79:387-396. https:/doi.org/10.1158/ 0008-5472.can-18-1834

86. Minutolo NG, Hollander EE, Powell DJ Jr (2019) The emergence of universal immune receptor T cell therapy for cancer. Front Oncol 9:176. https://doi. org/10.3389/fonc.2019.00176

87. Liu E, Marin D, Banerjee P et al (2020) Use of CAR-transduced natural killer cells in CD19-positive lymphoid tumours. N Engl J Med 382:545-553. https://doi.org/10.1056/nejmoa1910607

88. Natarajan A, Mayer AT, Reeves RE, Nagamine CM, Gambhir SS (2017) Development of novel immunoPET tracers to image human PD-1 checkpoint expression on tumour-infiltrating lymphocytes in a humanized mouse model. Mol Imaging Biol 19:903-914. https://doi.org/10.1007/s11307017-1060-3

89. Natarajan A, Mayer AT, Xu L, Reeves RE, Gano J, Gambhir SS (2015) Novel radiotracer for immunoPET imaging of PD-1 checkpoint expression on tumour infiltrating lymphocytes. Bioconjug Chem 26:2062-2069. https://doi. org/10.1021/acs.bioconjchem.5b00318

90. Verhoeff SR, van den Heuvel MM, van Herpen CM, Piet B, Aarntzen EH Heskamp S (2020) Programmed cell Death-1/Ligand-1 PET imaging: a novel tool to optimize immunotherapy? PET Clin 15:35-43. https://doi.org/10. 1016/j.cpet.2019.08.008

91. Bensch F, van der Veen EL, Lub-de Hooge MN et al (2018) 89Zratezolizumab imaging as a non-invasive approach to assess clinical response to PD-L1 blockade in cancer. Nat Med 24:1852-1858. https://doi. org/10.1038/s41591-018-0255-8

92. Niemeijer A, Leung D, Huisman M et al (2018) Whole body PD-1 and PD-L1 positron emission tomography in patients with non-small-cell lung cancer. Nat Commun 9:4664. https://doi.org/10.1038/s41467-018-07131-y

93. Gibson HM, McKnight BN, Malysa A et al (2018) IFNy PET imaging as a predictive tool for monitoring response to tumour immunotherapy. Cancer Res 78:5706-5717. https://doi.org/10.1158/0008-5472.can-18-0253

94. Larimer BM, Wehrenberg-Klee E, Dubois F et al (2017) Granzyme B PET imaging as a predictive biomarker of immunotherapy response. Cancer Res 77:2318-2327. https://doi.org/10.1158/0008-5472.can-16-3346

95. Markovic SN, Galli F, Suman VJ et al (2018) Non-invasive visualization of tumour infiltrating lymphocytes in patients with metastatic melanoma undergoing immune checkpoint inhibitor therapy: a pilot study. Oncotarget 9: 30268-30278. https:/doi.org/10.18632/oncotarget.25666

96. Ting DS, Liu Y, Burlina P, Xu X, Bressler NM, Wong TY (2018) Al for medical imaging goes deep. Nat Med 24:539-540. https://doi.org/10.1038/s41591018-0029-3

97. Wu M, Zhang Y, Zhang Y, Liu Y, Wu M, Ye Z (2019) Imaging-based biomarkers for predicting and evaluating cancer immunotherapy response. Radiol Imag Cancer 1:e190031. https://doi.org/10.1148/rycan.2019190031

\section{Publisher's Note}

Springer Nature remains neutral with regard to jurisdictional claims in published maps and institutional affiliations.

\section{Submit your manuscript to a SpringerOpen ${ }^{\circ}$ journal and benefit from:}

- Convenient online submission

- Rigorous peer review

- Open access: articles freely available online

- High visibility within the field

- Retaining the copyright to your article

Submit your next manuscript at $\boldsymbol{\nabla}$ springeropen.com 